\title{
PARTICIPANT'S RISK PERCEPTION AND ATTITUDE TOWARDS THE PANDEMIC OF H1N1 INFLUENZA \& ITS VACCINE.
}

Prashant Dahire, Amol Gaikwad, Vandana Kakrani, Rajesh Lakade Deepali Deo, Vinod Vedpathak, Girish Thitte
1. Assistant Professor, Department of Preventive \& Social Medicine, Swami Ramanand Tirtha Rural Govt. Medical College, Ambajogai.
2. District Programme Officer, Department of Preventive \& Social Medicine, NCD, Civil Hospital Gadchiroli
3. Professor, Department of Preventive \& Social Medicine, D.Y.Patil Medical College, Pune.
4. Associate Professor, Department of Preventive \& Social Medicine, BJ Medical College, Pune.
5. Assistant Professor, Department of Preventive \& Social Medicine, SRTR GMC, Ambajogai.
6. Assistant Professor, Department of Preventive \& Social Medicine, SRTR GMC, Ambajogai.
7. Assistant Professor, Department of Preventive \& Social Medicine, SRTR GMC, Ambajogai.

\section{CORRESPONDING AUTHOR}

Dr. Prashant Dahire,

Near Dr Ambedkar Colony,

Beed Road, Morewadi, Ambajogai

Dist Beed - 431517

E-mail: prashantdahire@gmail.com

Ph: 00919423168185

INTRODUCTION: In April 2009, the Mexican Secretariat of Health reported an outbreak of respiratory disease. In affected patients, a novel swine origin influenza A (H1N1 09) virus was detected. Evidence that this new strain could pass from human to human led the World Health Organization (WHO) to quickly raise its pandemic alert level to phase 5 on 29 April 20091. In the world up to January 2010, 209 countries \& overseas territories were reported laboratory confirmed cases of pandemic H1N1. In addition at least 15,174 deaths related to this infection had been recorded 2 . In India up to November 2010, 44,101 laboratory confirmed cases and 2,679 deaths due to H1N1 influenza were reported ${ }^{3}$.

According to the recommendations from WHO, all countries should immunize their Healthcare Workers as a priority in order to protect the vital health infrastructure ${ }^{4}$. We surveyed a sample of Healthcare Workers from Ambajogai, Dist. Beed, Maharashtra with the objective, to ascertain their risk perception and attitude towards the pandemic H1N1 and its vaccine. And also change in behaviour of healthcare workers due to pandemic H1N1.

MATERIAL AND METHODS: STUDY DESIGN AND STUDY AREA: study was carried out in Government medical college Hospital of Ambajogai, i.e. Swami Ramanand Teerth Rural Medical College, Ambajogai, District Beed, Which is one of the rural medical college of India, serving mainly rural population. We conducted a cross sectional survey among Healthcare Workers of S.R.T.R.Medical College, Ambajogai, Dist. Beed, Maharashtra, between November and December 2010.

STUDY SUBJECTS: All HealthCare Workers of medical college hospital i.e. Doctors, nursing staff male and female, technicians and ward boys who were constantly exposed to patients were our target population. Out of them those healthcare workers were present at the time of survey, were included in the study. Thus a total of 236 healthcare workers were included in the study. 
DATA COLLECTION: For Pandemic H1N1 a vernacular alternative i.e. Swine flu was used. A team of trained research associates collected the data for this study. Data were collected with the help of pre-tested, semi structured questionnaire. The questionnaire consists of four sections. In first section data regarding the personal information of study subjects were collected. In second and third section data regarding study subject's risk perception and attitude towards pandemic H1N1 and its vaccine were collected. And in fourth section data regarding study subject's behavioural modifications in response to pandemic H1N1 were collected.

ETHICAL APPROVAL: Research protocol was approved by institutional ethical committee of medical college. The informed consent was taken from each study subject.

DATA ANALYSIS: data was entered in Microsoft excel sheet, then imported to Epi Info software windows version (3.5.1) and analysed.

RESULTS: Table 1 shows age and sex distribution of study participants out of 236 participants $140(59.3 \%)$ were male and 96 (40.7\%) were female. Participants were younger with $59.4 \%$ of study participants aged $<35$ years.

Majority i.e.49.1\% participants rated the average Ambajogai resident's risk of acquiring H1N1 as "very high" to "high" while the remainder rated the risk as "medium" i.e. $25.4 \%$, or "very low to low" i.e. $10.2 \%(24 / 236)$. Rating of their own risk followed a similar pattern with majority i.e. $62.7 \%(148 / 236)$ rating it at "very high" to "high". 88.1\% (208/236) of participants believed the current H1N1 situation was serious. While $54.2 \%$, believed that they had no control over whether they got "swine flu". 50.8\% had not witnessed their friends or family having "swine flu" and $44.1 \%$ also believed people were still going to catch it six months time. If acquired, $44.1 \%$ of participants rated pandemic H1N1 influenza "somewhat affect" their own health, while a $23.7 \%$, thought their health would be "very seriously" affected. Of concern, $33.9 .0 \%$ of participants did not understand what was happening with the "swine flu" pandemic (Table 2).

One or more changes to behaviour were reported in response to the swine flu situation by most of the participants (96.1\%). The most common changes included hand cleansing through increased hand washing (94.9\%) and the use of alcoholic hand gel (81.4\%) (Table 3)

Overall likelihood of accepting vaccination against H1N1 vaccine was 94.9\% (224). A common supportive reason was "if recommended by doctor" (91.5\%) and "if recommended by Indian government" $(89.8 \%)$, followed by the belief that the vaccine would provide protection against the disease $(69.5 \%)$. But the concerns about side effects due to vaccine $(74.6 \%)$ and adequacy of testing the vaccine $(47.5 \%)$ were there in the participants (Table 4). Some participants classified themselves at high risk of influenza and therefore believed it was extremely important to be vaccinated, whereas others expressed an obligation to be vaccinated because of work commitments. A general belief or confidence in vaccination was commonly expressed as a reason for accepting the vaccine.

Participants who rated their level of risk of acquiring H1N1 infection high to very high were 3.57 times more likely to intended to be vaccinated. Also the participants who perceived H1N1 situation as serious one and who undertake .1 behavioural change in response to H1N1 pandemic were 9.02 times and 138.3 times respectively more intended to vaccinated with H1N1 vaccine. 
DISCUSSION: A novel influenza A H1N1 virus, quite different from the circulating seasonal influenza viruses which got noticed in Mexico in April, 2009, spread fast across the globe during 2009-10. On 11 th June, 2009, World Health Organization declared this a pandemic. It affected over 200 countries globally including India. ${ }^{3}$

We found that more than $50 \%$ of study participant perceived that they were at significantly high risk of acquiring H1N1. This is perhaps not surprisingly because there is perception of risk amongst the community, as many of the reports on H1N1 cases in the newspapers and other media channels made regularly. The acceptance of, and adherence to public health measures by the population depends largely on the way people perceive a threat.

We also observed that change in behaviour in response to the swine flu situation by most of the participants (96.1\%). The most common changes included hand cleansing through increased hand washing (94.9\%), this was due to and also all the participants were healthcare worker and regular guidelines and education were given to them during this period by the authorities. It was not also surprising that few of our participants reported to keep away from public places and public transportation

One important prevention / mitigation strategy is vaccinating the at risk population with Pandemic Vaccine. Ministry of Health \& FW, Government of India has imported 1.5 million doses of vaccine to vaccinate selected population among the high risk group. ${ }^{5}$ In our study overall likelihood of accepting vaccination against $\mathrm{H} 1 \mathrm{~N} 1$ vaccine was $94.9 \%$ (224). A common supportive reason was "if recommended by doctor" (91.5\%) and "if recommended by Indian government" (89.8\%), followed by the belief that the vaccine would provide protection against the disease (69.5\%).Our findings suggest that there will be uptake of the vaccine if the Govt. of India made available it.

CONCLUSION: Most participants believe that they were at high risk of acquiring pandemic H1N1 influenza, which can also be concluded from the acceptance of behavioral changes in response to pandemic H1N1. As H1N1 influenza vaccine was made available, the participants who believe that situation of H1N1 is serious and who think that, they are at high to very high risk of H1N1 were more likely to intend to receive the H1N1 vaccine. But concerns about vaccine safety, possibility of side effects and the vaccine development process need to be addressed.

CONFLICTS OF INTEREST: none. Funding source: none

\section{References:}

1. Seale H, Heywood AE, Mclawa ML, Ward KF, Lowbridge CP, Van D, Maclntyre R. Why do I need it? I am not at risk! Public perceptions towards the pandemic (H1N1) 2009 vaccine. BMC infectious diseases.2010,10;99

2. World Health Organization (WHO). [internet]. Weekly update. Pandemic H1N1 2009update 86 available from : http://www.who.int/csr/don/2010_02_5

3. World Health Organization (WHO). [internet]. WHO recommendations on pandemic H1N1 2009 briefing note 2. available from http://www.who.int/crs/disease/swin

4. Swine flu India - A fight against pandemic. Available from http://www.swinefluindia.com 
5. Ministry of Health and Family Welfare, Government of India. Guidance on Pandemic Vaccination. Available from: http://mohfw-h1n1.nic.in/vaccine.html

Table 1: Age and Sex distribution of participants

\begin{tabular}{|l|l|l|}
\hline \multicolumn{2}{|l|}{} & $\begin{array}{l}\text { No. of participants } \\
(\mathrm{N}=236)\end{array}$ \\
\hline Sex & 140 & $59.3 \%$ \\
\hline Male & 96 & $40.7 \%$ \\
\hline Female & \multicolumn{2}{|l}{} \\
\hline Age groups(Yrs) & 24 & $10.2 \%$ \\
\hline $18-24$ & 116 & $49.2 \%$ \\
\hline $25-34$ & 44 & $18.6 \%$ \\
\hline $35-44$ & 40 & $16.9 \%$ \\
\hline $45-54$ & 12 & $5.1 \%$ \\
\hline $55-64$ &
\end{tabular}

Table 2: Participants risk perception and attitude towards pandemic H1N1

\begin{tabular}{|c|c|c|}
\hline Question & Response & $\%(\mathrm{~N}=236)$ \\
\hline $\begin{array}{l}\text { What level of risk do you think the average } \\
\text { Ambajogai Resident has of catching } \\
\text { H1N1Influenza or "Swine Flu" during this } \\
\text { pandemic? }\end{array}$ & $\begin{array}{l}\text { Very high-High } \\
\text { Medium } \\
\text { very low - low } \\
\text { Unsure - not specified }\end{array}$ & $\begin{array}{l}\mathbf{4 9 . 1 \% ( 1 1 6 )} \\
25.4 \%(60) \\
10.2 \%(24) \\
15.3 \%(36)\end{array}$ \\
\hline $\begin{array}{l}\text { What level of risk do you think you have of } \\
\text { catching Influenza A H1N1 or "Swine Flu" during } \\
\text { this pandemic? }\end{array}$ & $\begin{array}{l}\text { Very high-High } \\
\text { Medium } \\
\text { very low - low } \\
\text { Unsure - not specified }\end{array}$ & $\begin{array}{l}\mathbf{6 2 . 7 \% ( 1 4 8 )} \\
20.3 \%(48) \\
11.9 \%(28) \\
5.1 \%(12)\end{array}$ \\
\hline $\begin{array}{l}\text { In general, I think the authorities are doing a good } \\
\text { job of dealing with the "Swine Flu" pandemic }\end{array}$ & $\begin{array}{l}\text { Agree } \\
\text { Disagree } \\
\text { Unsure - not specified }\end{array}$ & $\begin{array}{l}72.9 \%(172) \\
23.7 \%(56) \\
3.4 \%(8)\end{array}$ \\
\hline $\begin{array}{l}\text { I think the current "Swine Flu" situation is } \\
\text { serious }\end{array}$ & $\begin{array}{l}\text { Agree } \\
\text { Disagree }\end{array}$ & $\begin{array}{l}88.1 \%(208) \\
11.9 \%(28)\end{array}$ \\
\hline $\begin{array}{l}\text { I think that whether I acquired the "Swine Flu" or } \\
\text { not is out of my control }\end{array}$ & $\begin{array}{l}\text { Agree } \\
\text { Disagree } \\
\text { Unsure - not specified }\end{array}$ & $\begin{array}{l}54.2 \%(128) \\
33.9 \%(80) \\
11.9 \%(28)\end{array}$ \\
\hline
\end{tabular}




\begin{tabular}{|c|c|c|}
\hline $\begin{array}{l}\text { Have there been cases of "Swine Flu" amongst } \\
\text { your family or friends? }\end{array}$ & $\begin{array}{l}\text { Yes } \\
\text { No } \\
\text { Unsure - not specified }\end{array}$ & $\begin{array}{l}2.2 \%(5) \\
50.8 \%(120) \\
47 \%(111)\end{array}$ \\
\hline $\begin{array}{l}\text { In my opinion, people are still going to be catching } \\
\text { "Swine Flu" six months from now }\end{array}$ & $\begin{array}{l}\text { Agree } \\
\text { Disagree } \\
\text { Unsure - not specified }\end{array}$ & $\begin{array}{l}44.1 \%(104) \\
15.3 \%(36) \\
40.6 \%(96)\end{array}$ \\
\hline $\begin{array}{l}\text { If you were infected with "Swine Flu", how } \\
\text { seriously do you think it would affect your } \\
\text { health? }\end{array}$ & $\begin{array}{l}\text { Not at all } \\
\text { Somewhat affect } \\
\text { Extremely - Very seriously } \\
\text { Unsure - not specified }\end{array}$ & $\begin{array}{l}5.1 \%(12) \\
44.1 \%(104) \\
44 \%(104) \\
6.8 \%(16)\end{array}$ \\
\hline $\begin{array}{l}\text { I do not understand what is happening with this } \\
\text { "Swine Flu" pandemic }\end{array}$ & $\begin{array}{l}\text { Agree } \\
\text { Disagree } \\
\text { Unsure - not specified }\end{array}$ & $\begin{array}{l}33.9 \%(80) \\
49.2 \%(116) \\
16.9 \%(40)\end{array}$ \\
\hline
\end{tabular}

Table 3: Behavioural responses to pandemic H1N1

\begin{tabular}{|l|l|}
\hline Behavioural change due to Swine flu & $\begin{array}{l}\%(\mathrm{n}) \text { of positive } \\
\text { responses }\end{array}$ \\
\hline Washed my hands with soap and water more often than usual & $94.9 \%(224)$ \\
\hline Used alcoholic hand gel more than usual & $81.4 \%(192)$ \\
\hline $\begin{array}{l}\text { Increased the amount I clean or disinfect things that I might touch, } \\
\text { such as door knobs }\end{array}$ & $78 \%(184)$ \\
\hline Kept away from crowded places generally & $67.8 \%(160)$ \\
\hline Reduced the frequency I use public transport & $32.2 \%(76)$ \\
\hline $\begin{array}{l}\text { Deliberately cancelled or postponed a social event, such as meeting } \\
\text { friends, eating out or going to a sport event }\end{array}$ & $27.1 \%(64)$ \\
\hline Reduced the frequency I go into shops & $28.8 \%(68)$ \\
\hline Kept one or more of my children out of school or pre-school & $16.9 \%(40)$ \\
\hline
\end{tabular}


Table 4: Participants risk perception and attitude towards H1N1 influenza vaccine.

\begin{tabular}{|c|c|c|}
\hline Question & Response & $\%(\mathrm{~N}=236)$ \\
\hline $\begin{array}{l}\text { If a "Swine Flu" vaccine was made available to } \\
\text { the general public, would you get vaccinated? }\end{array}$ & $\begin{array}{l}\text { Yes } \\
\text { No } \\
\text { Not specified }\end{array}$ & $\begin{array}{l}\mathbf{9 4 . 9 \% ( 2 2 4 )} \\
3.4 \%(8) \\
1.7 \%(4)\end{array}$ \\
\hline $\begin{array}{l}\text { Only people who are have underlying medical } \\
\text { problems or who are pregnant should be } \\
\text { vaccinated? }\end{array}$ & $\begin{array}{l}\text { Agree } \\
\text { Disagree } \\
\text { Unsure - not specified }\end{array}$ & $\begin{array}{l}20.3 \%(48) \\
72.9 \%(172) \\
6.8 \%(16) \\
\end{array}$ \\
\hline $\begin{array}{l}\text { I will get "Swine Flu" vaccine if the Indian } \\
\text { Government recommends it? }\end{array}$ & $\begin{array}{l}\text { Agree } \\
\text { Disagree } \\
\text { Unsure - not specified }\end{array}$ & $\begin{array}{l}89.8 \%(212) \\
8.5 \%(20) \\
1.7 \%(4)\end{array}$ \\
\hline $\begin{array}{l}\text { I will get "Swine Flu" vaccine if my doctor } \\
\text { recommends it? }\end{array}$ & $\begin{array}{l}\text { Agree } \\
\text { Disagree } \\
\text { Unsure - not specified }\end{array}$ & $\begin{array}{l}91.5 \%(216) \\
5.1 \%(12) \\
3.4 \%(8) \\
\end{array}$ \\
\hline $\begin{array}{l}\text { I am concerned about the side effects of the } \\
\text { "Swine Flu" vaccine? }\end{array}$ & $\begin{array}{l}\text { Agree } \\
\text { Disagree } \\
\text { Unsure - not specified }\end{array}$ & $\begin{array}{l}74.6 \%(176) \\
16.9 \%(40) \\
8.5 \%(20)\end{array}$ \\
\hline $\begin{array}{l}\text { I am concerned that the vaccine has not been } \\
\text { tested adequately? }\end{array}$ & $\begin{array}{l}\text { Agree } \\
\text { Disagree } \\
\text { Unsure - not specified }\end{array}$ & $\begin{array}{l}47.5 \%(112) \\
42.4 \%(100) \\
10.1 \%(36)\end{array}$ \\
\hline $\begin{array}{l}\text { The "Swine Flu" vaccine may cause the Flu in } \\
\text { some people? }\end{array}$ & $\begin{array}{l}\text { Agree } \\
\text { Disagree } \\
\text { Unsure - not specified }\end{array}$ & $\begin{array}{l}55.9 \%(132) \\
23.7 \%(56) \\
20.4 \%(48)\end{array}$ \\
\hline $\begin{array}{l}\text { The "Swine Flu" vaccine will protect me from } \\
\text { the disease? }\end{array}$ & $\begin{array}{l}\text { Agree } \\
\text { Disagree } \\
\text { Unsure - not specified }\end{array}$ & $\begin{array}{l}69.5 \%(164) \\
3.4 \%(8) \\
27.1 \%(64)\end{array}$ \\
\hline $\begin{array}{l}\text { The "Swine Flu" vaccine will stop the spread of } \\
\text { "Swine Flu"? }\end{array}$ & $\begin{array}{l}\text { Agree } \\
\text { Unsure - not specified }\end{array}$ & $\begin{array}{l}50.8 \%(120) \\
49.2 \%(116)\end{array}$ \\
\hline
\end{tabular}

Table 5: Willingness of survey participants to accept H1N1 influenza vaccine.

\begin{tabular}{|l|l|l|l|}
\hline Variable & \multicolumn{2}{|l|}{ Stated acceptance of H1N1 vaccine } & $\begin{array}{l}\text { Odds ratio (CI 95) } \\
\text { (p value) }\end{array}$ \\
\cline { 2 - 4 } & $\begin{array}{l}\text { Yes }(\mathrm{N}=224) \\
\%(\mathrm{n})\end{array}$ & $\begin{array}{l}\text { No/Not specified (N=12) } \\
\%(\mathrm{n})\end{array}$ & $\begin{array}{l}3.57(1.04-14.01) \\
(\mathrm{p}<0.05)\end{array}$ \\
\hline $\begin{array}{l}\text { High to very high } \\
\text { personal risk of H1N1 } \\
\text { infection }\end{array}$ & $62.5 \%(144)$ & $66.6 \%(4)$ & $\begin{array}{l}9.02(2.55-32.04)) \\
(\mathrm{p}<0.05)\end{array}$ \\
\hline $\begin{array}{l}\text { Perceives H1N1 } \\
\text { situation as serious }\end{array}$ & $86.6 \%(201)$ & $83.3(6)$ & $\begin{array}{l}138.3(24.75-1176) \\
(\mathrm{p}<0.05)\end{array}$ \\
\hline $\begin{array}{l}\text { Undertaken } \\
\text { behavioural change due } \\
\text { to H1N1 pandemic }\end{array}$ & $95.9 \%(222)$ & $91.6 \%(5)$ & \\
\hline
\end{tabular}

